\begin{tabular}{|c|c|c|}
\hline Beitr. Ent. & Keltern & ISSN 0005-805X \\
\hline $\mathbf{6 0}(2010) 2$ & S. $471-487$ & 20.12 .2010 \\
\hline
\end{tabular}

\title{
A phylogenetic framework for the bumblebee species of the subgenus Bombus sensu stricto based on mitochondrial DNA markers, with a short description of the neglected taxon B. minshanicola BISCHOFF, 1936 n. status.
}

\section{(Hymenoptera: Apidae: Bombus)}

With 4 figures and 5 tables

\section{Andreas Bertsch}

\section{Zusammenfassung}

Königinnen von 12 Taxa der Untergattung Bombus sensu stricto (Bombus affinis, B. albocinctus, B. cryptarum, B. lucorum, B. magnus, B. moderatus, B. occidentalis, B. patagiatus, B. sporadicus, B. terrestris, B. terricola and $B$. tunicatus) wurden im Frühjahr gefangen, um künstliche Kolonien zu züchten. Zusätzlich wurden Männchen von B. franklini und B. lucorum/China gefangen. Mitochondriale Cytochrome Oxidase Untereinheit I (COI) von 53 Proben wurde sequenziert (Teilsequenzen der Länge 1257 bp). GenBank Sequenzen der Ostasiatischen Arten B. hypocrita, B. ignitus und B. lucorum/China wurden einbezogen. Der Unterschied zwischen den Arten beträgt 30 - 92 Basen-Substitutionen und die Tamura-Nei genetische Distanz 0.030-0.103, während der Unterschied innerhalb der Arten nur $1-3$ Basensubstitution beträgt und die Tamura-Nei genetische Distanz nur 0.001-0.003. Dreizehn Taxa mit Artrang sowie eine neue Art B. minshanicola BisCHOFF 1936 ( $=$ B. terrestris ssp. minshanicola $=B$. lucorum/China) wurden nachgewiesen. In der Topologie des phylogenetischen Stammbaums gibt es 4 Cluster: ein Artenpaar B. sporadicus - B. ignitus und ein Artenpaar B. terricola - B. occidentalis, ein Cluster für B. magnus, B. patagiatus and B. cryptarum mit den Subspecies B. cryptarum albocinctus und B. cryptarum moderatus sowie ein Cluster für B. hypocrita, B. lucorum, B. minshanicola, B. franklini and B. affinis. Die Arten B. terrestris mit den Subspecies B. terrestris canariensis und $B$. terrestris sassaricus sowie $B$. tunicatus sind einzeln abgetrennt. Da sich im Alignment der COI Sequenzen keine Lücken finden, können die einzelnen Nucleotid-Positionen als homolog betrachtet werden. Jede Art besitzt eine Reihe einzigartiger ('privater') Positionen, die als diagnostische Merkmale benutzt werden können um die Art zu definieren und zu identifizieren.

\section{Summary}

Queens of 12 taxa of the subgenus Bombus sensu stricto (Bombus affinis, B. albocinctus, B. cryptarum, B. lucorum, B. magnus, B. moderatus, B. occidentalis, B. patagiatus, B. sporadicus, B. terrestris, B. terricola and B. tunicatus) were collected in spring to establish artificial colonies. Males of B. franklini and B. lucorum/ China were also collected. Mitochondrial cytochrome oxidase subunit I (COI) was sequenced from 53 specimens (partial sequence length $1257 \mathrm{bp}$ ). GenBank sequences of the east Asiatic species B. hypocrita and $B$. ignitus were included in the investigation. The interspecific sequence diversity was about 30-92 base substitutions with a Tamura-Nei genetic distance of $0.030-0.103$, whereas the intraspecific sequence diversity was only $1-3$ base substitutions with a Tamura-Nei genetic distance of $0.001-0.003$. Thirteen Taxa ranked as species were found and a new taxon ranked as species B. minshanicola Bischoff $1936(=B$. terrestris ssp. minshanicola $=B$. lucorum /China) was established. Four clusters were obtained in the topology of the 
phylogenetic tree: a species pair B. ignitus - B. sporadicus, a species pair B. terricola - B. occidentalis, a cluster including B. magnus, B. patagiatus and B. cryptarum with ssp. B. cryptarum albocinctus and B. cryptarum moderatus, and a cluster including $B$. hypocrita, $B$. lucorum, B. minshanicola, $B$. franklini and B. affinis. The species $B$. terrestris with ssp. $B$. terrestris canariensis and $B$. terrestris sassaricus and $B$. tunicatus were well separated. As there are no gaps in the alignment of the COI sequences, single nucleotide sites can be used as positional homologies. Each taxon is characterized by substitutions that are unique and can be used as diagnostic characters to define and identify the taxon.

\section{Introduction}

With the recent publications of Pedersen (1996, 2002), Kawakita et al. (2004) and Cameron et al. (2007) we have a good general picture of the phylogenetic relationships of most bumblebee species, and much insight into the deeper nodes of phylogeny. However, many questions remain at the terminal units of the branches, and we need more specimens from a broad range of geographical localities to investigate the genetic polymorphism of the taxa and to understand the phylogenetic relationships within subgenera. The mitochondrial DNA marker cytochrome oxidase I (COI) has proven to be useful because the genetic difference between the taxa is about one order of magnitude larger (Pedersen 2002; Bertsch 2009; Bertsch et al. 2010a, 2010b) than in nuclear genes (Kawakita et al. 2004; Cameron et al. 2007).

The use of single nucleotide positions as homologue characters is a useful tool for the construction of cladistic trees, and the use of nucleotide positions that are unique for critical taxa enables safe identification (BERTSCH 2009). As these unique positions depend on the number of species included in the comparison it seems to be necessary to include all known species of a group. This approach was taken in this investigation of the subgenus Bombus sensu stricto, a subgenus that is well defined by the very special form of the male genital capsule, especially the funnel-shaped penis valves (VogT 1909).

\section{Materials and methods}

\section{Bumblebee samples}

Table 1 shows the bumblebee samples used for DNA sequencing, their identification codes and the localities of their origin with geographical coordinates. For comparison GenBank sequences of East Asian taxa in particular were included (Table 2). As some of these GenBank sequences are shorter in length the sequences had to be clipped to equal length for some calculations.

Cameron et al. (2007) reported that B. lucorum is split into a European (B. lucorum) and a Chinese taxon (B. lucorum/China), with obviously different DNA in the 16S mitochondrial gene and the four nuclear genes investigated. An unpublished COI GenBank sequence GU085202 (B. lucorum from North China) confirmed this result. Therefore specimens of B. lucorum from China/Sichuan (collected by Dr. van Asperen de Boer, Amsterdam) and a male specimen of B. lucorum from China/Gansu (supplied by Dr. AN, Beijing) were sequenced.

\section{Polymerase chain reaction (PCR) and DNA sequencing of mitochondrial COI}

Total DNA was extracted from legs using the QIAamp ${ }^{\circ}$ DNA Mini Kit (Qiagen, Hilden, Germany) according to the manufacturer's specifications for tissue, and eluted in $150 \mu \mathrm{l}$ of highly purified water (Ampuwa', Fresenius Kabi, Bad Homburg, 
Germany). For sequence analysis overlapping fragments (in all $1257 \mathrm{bp}$ ) of mitochondrial COI were amplified using primers specifically designed for Bombus. BO-0-fwd (5'GAATAATATATTTTATTTTTGC3') and BO-Z-rev (5'CCAAAAAATCAAAATAAATGTTG3') resulted in theamplification ofa 671 bp fragment, BO-1-fwd (5'TAGGATCACCAGATATAGC3') and BO-K-rev (5' GAGCTCAAACAATAAATCC 3') resulted in the amplification of a 609 bp fragment, and BO-5-fwd (5' AATGAAAGAGGTAAAAAAGAAAC 3') and BO-A-rev (5' ATGTTGAGGGAAAAATGTTAT 3') resulted in the amplification of a $510 \mathrm{bp}$ fragment. PCR amplifications were performed in $50 \mu \mathrm{l}$ reactions containing $100 \mathrm{ng}$ DNA template,

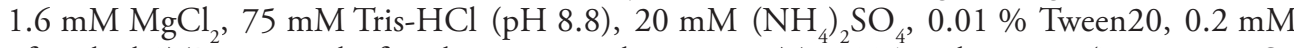
of each dNTP, 20 pmol of each primer and 1.5 units TaqDNA polymerase (Fermentas, St. Leon-Rot, Germany). Conditions for PCR amplification were initial denaturation for $5 \mathrm{~min}$ at $94^{\circ} \mathrm{C}, 40$ cycles of $45 \mathrm{~s}$ denaturation at $94^{\circ} \mathrm{C}, 1 \mathrm{~min}$ annealing at $46^{\circ} \mathrm{C}, 3 \mathrm{~min}$ elongation at $62{ }^{\circ} \mathrm{C}$ (for BO-0-fwd and BO-Z-rev), at $61{ }^{\circ} \mathrm{C}$ (for BO-1-fwd and BO-K-rev) and $63{ }^{\circ} \mathrm{C}$ (for BO-5-fwd and BO-A-rev), and final extension for $7 \mathrm{~min}$. Ten $\mu \mathrm{l}$ of each reaction was checked on a $1 \%$ agarose gel. PCR products were purified using an AMPure ${ }^{\oplus}$ PCR Purification Kit (Agencourt, Beverly, MA, USA). Sequencing reactions were performed using $\mathrm{ABI}^{\oplus} \mathrm{BigDye}$ Terminator version 3.1 chemistry (Applied Biosystems, Foster City, CA, USA) according to the manufacturer's instructions, all fragments were sequenced from both strands and then analysed on an ABI 3100 sequencer (Applied Biosystems). Sequences were aligned manually using ClustalX. No gaps or poorly aligned regions occurred in the alignment, but missing characters were trimmed from the ends of the alignment to produce an equal sequence length of $1257 \mathrm{bp}$ for all individuals (encoding 419 amino acids). Individual alignments were aligned against the complete COI gene sequence of Bombus ignitus (GenBank accession no. DQ870926; CHA et al. 2007) between positions 262 and 1519.

\section{Analysis of sequence divergence of mitochondrial COI}

The absolute numbers of substitutions were counted based on a pair wise comparison of COI sequences. The analysis for the sequences investigated was performed using the maximum composite likelihood method of Mega 4.0 (TAmura et al. 2007; Kumar et al. 2008), a program distributed by K. Tamura, J. Dudley, M. Nei and S. Kumar. Because the distribution of nucleotides in the COI of Hymenoptera is known to be heterogeneous, with a strong $\mathrm{A}+\mathrm{T}$ bias, we selected the Tamura-Nei (TN) model of base substitution (TAMura and Nei 1993), which corrects this bias in its assumption of sequence evolution. The nucleotide frequencies and the parameters necessary for this model were estimated from the sequence data, and TN genetic distances were calculated. The best maximum likelihood model was selected using the jModelTest (PosADa 2008). The tree topology was inferred by a maximum likelihood tree based on the general time-reversible model (GTR plus gamma) calculated by Bayesian analysis (Huelsenbeck and RonQuist 2001) using MrBayes, a program distributed by J. P. Huelsenbeck and F. Ronquist. Tree topology was also calculated as a Minimum Evolution tree (ME) with bootstrap sampling, using Mega 4.0 (Kumar et al. 2008). Geneious Pro 4.5 (Biomatters Ltd.) was used to analyse the alignment and detect diagnostic positions, and the GreenButton plugin (InterGrid) was used to perform the time-consuming MrBayes calculations on a supercomputer cluster. The nucleotide changes along the branches of cladograms were examined with MacClade 3.04. The COI sequence data of B. soroeensis (GenBank accession no. AY181159; PEDERSEn 2002) were used as an out-group. 
Tab. 1: List of Bombus samples $($ AfF $=$ affinis, $\mathrm{CRY}=$ cryptarum, $\mathrm{BUR}=$ cryptarum burjaeticus, $\mathrm{MoD}=$ cryptarum moderatus, $\mathrm{LUC}=$ lucorum, $\mathrm{MAG}=$ magnus, $\mathrm{MIN}=$ minshanicola, OCC $=$ occidentalis, $\mathrm{PAT}=$ patagiatus, SPO $=$ sporadicus, TERRE $=$ terrestris, SAS $=$ terrestris sassaricus, CAN $=$ terrestris canariensis, TERRI $=$ terricola and Tun $=$ tunicatus) used in the present analysis with identification codes, and collection locality information. $\mathrm{Q}=$ ㅇ ㅇ, $\mathrm{aC} \rightarrow \mathrm{M}=$ artificial colonies with production of males.

\begin{tabular}{|c|c|c|c|c|c|c|c|}
\hline Code & Locality & \begin{tabular}{|l|} 
Country \\
\end{tabular} & Region & Latitude & Longitude & Altitude & \\
\hline Aff- 01 & Boston & USA & Massachusetts & $42^{\circ} 17.87^{\prime} \mathrm{N}$ & $71^{\circ} 07.35^{\prime} \mathrm{W}$ & $19 \mathrm{~m}$ & $\mathrm{Q}, \mathrm{aC} \rightarrow \mathrm{M}$ \\
\hline Aff- 02 & Marconi Beach & USA & Massachusetts & $41^{\circ} 53.45^{\prime} \mathrm{N}$ & $69^{\circ} 57.75^{\prime} \mathrm{W}$ & $8 \mathrm{~m}$ & QQ \\
\hline Aff- 03 & Bridgewater & USA & Massachusetts & $41^{\circ} 59.05^{\prime} \mathrm{N}$ & $70^{\circ} 59.16^{\prime} \mathrm{W}$ & $30 \mathrm{~m}$ & $\mathrm{Q}, \mathrm{aC} \rightarrow \mathrm{M}$ \\
\hline Aff- 04 & New Hampton & USA & New Hampshire & $43^{\circ} 36.48^{\prime} \mathrm{N}$ & $71^{\circ} 39.26^{\prime} \mathrm{W}$ & $175 \mathrm{~m}$ & $\mathrm{Q}, \mathrm{aC} \rightarrow \mathrm{M}$ \\
\hline Cry-01 & Duncery Beacon & UK & England & $51^{\circ} 09.48^{\prime} \mathrm{N}$ & $3^{\circ} 34.64^{\prime} \mathrm{W}$ & $417 \mathrm{~m}$ & $\mathrm{Q}, \mathrm{aC} \rightarrow \mathrm{M}$ \\
\hline Cry-02 & Marcinkonys & Lithuania & Alytus County & $54^{\circ} 21.04^{\prime} \mathrm{N}$ & $24^{\circ} 25.46^{\prime} \mathrm{E}$ & $145 \mathrm{~m}$ & $\mathrm{Q}, \mathrm{aC} \rightarrow \mathrm{M}$ \\
\hline Cry-03 & Strelna & Russia & St. Petersburg & $59^{\circ} 51.63^{\prime} \mathrm{N}$ & $30^{\circ} 05.33^{\prime} \mathrm{E}$ & $3 \mathrm{~m}$ & $\mathrm{Q}, \mathrm{aC} \rightarrow \mathrm{M}$ \\
\hline Cry-04 & Nassfeld & Austria & Kärnten & $46^{\circ} 34.49^{\prime} \mathrm{N}$ & $13^{\circ} 06.26^{\prime} \mathrm{E}$ & $1415 \mathrm{~m}$ & $\mathrm{Q}, \mathrm{aC} \rightarrow \mathrm{M}$ \\
\hline Bur-01 & Kadachta & Russia & Karymski District & $51^{\circ} 37.22^{\prime} \mathrm{N}$ & $114^{\circ} 14.56^{\prime} \mathrm{E}$ & $650 \mathrm{~m}$ & $\mathrm{Q}, \mathrm{aC} \rightarrow \mathrm{M}$ \\
\hline Bur-02 & Chita & Russia & Zabaikalsky Krai & $52^{\circ} 00.54^{\prime} \mathrm{N}$ & $113^{\circ} 28.35^{\prime} \mathrm{E}$ & $750 \mathrm{~m}$ & $\mathrm{Q}, \mathrm{aC} \rightarrow \mathrm{M}$ \\
\hline Mod-01 & Isabel Pass & USA & Alaska & $63^{\circ} 11.77^{\prime} \mathrm{N}$ & $145^{\circ} 33.64^{\prime} \mathrm{W}$ & $1095 \mathrm{~m}$ & $\mathrm{Q}, \mathrm{aC} \rightarrow \mathrm{M}$ \\
\hline Mod-02 & Broad Pass & USA & Alaska & $63^{\circ} 19.31^{\prime} \mathrm{N}$ & $149^{\circ} 09.21^{\prime} \mathrm{W}$ & $725 \mathrm{~m}$ & $\mathrm{Q}, \mathrm{aC} \rightarrow \mathrm{M}$ \\
\hline Mod-03 & Ya-Ha-Tinda Ranch & Canada & Alberta & $51^{\circ} 44.57^{\prime} \mathrm{N}$ & $115^{\circ} 32.52^{\prime} \mathrm{W}$ & $1615 \mathrm{~m}$ & Q \\
\hline Mod-04 & Sheep River & Canada & Alberta & $50^{\circ} 39.11^{\prime} \mathrm{N}$ & $114^{\circ} 21.85^{\prime} \mathrm{W}$ & $1315 \mathrm{~m}$ & M \\
\hline Fra- 01 & Gold Hill & USA & Oregon & $42^{\circ} 25.81^{\prime} \mathrm{N}$ & $123^{\circ} 02.69^{\prime} \mathrm{W}$ & $330 \mathrm{~m}$ & worker \\
\hline Luc-01 & Marcinkonys & Lithuania & Alytus County & $54^{\circ} 21.04^{\prime} \mathrm{N}$ & $24^{\circ} 25.46^{\prime} \mathrm{E}$ & $145 \mathrm{~m}$ & $\mathrm{Q}, \mathrm{aC} \rightarrow \mathrm{M}$ \\
\hline Luc-02 & Col de Vars & France & Hautes Alpes & $44^{\circ} 32.25^{\prime} \mathrm{N}$ & $6^{\circ} 42.21^{\prime} \mathrm{E}$ & $2112 \mathrm{~m}$ & $\mathrm{Q}, \mathrm{aC} \rightarrow \mathrm{M}$ \\
\hline Luc-03 & Chita & Russia & Chitinskaja Obl. & $52^{\circ} 00.86^{\prime} \mathrm{N}$ & $113^{\circ} 28.56^{\prime} \mathrm{E}$ & $730 \mathrm{~m}$ & $\mathrm{Q}, \mathrm{aC} \rightarrow \mathrm{M}$ \\
\hline Mag-01 & Glen Oykel & UK & Scotland & $57^{\circ} 59.74^{\prime} \mathrm{N}$ & $4^{\circ} 49.11^{\prime} \mathrm{W}$ & $140 \mathrm{~m}$ & $\mathrm{Q}, \mathrm{aC} \rightarrow \mathrm{M}$ \\
\hline Mag-02 & Roth & Germany & Bayern & $49^{\circ} 14.61^{\prime} \mathrm{N}$ & $11^{\circ} 08.95^{\prime} \mathrm{E}$ & $372 \mathrm{~m}$ & $\mathrm{Q}, \mathrm{aC} \rightarrow \mathrm{M}$ \\
\hline Mag-03 & Marcinkonys & Lithuania & Alytus County & $54^{\circ} 21.04^{\prime} \mathrm{N}$ & $24^{\circ} 25.46^{\prime} \mathrm{E}$ & $145 \mathrm{~m}$ & $\mathrm{Q}, \mathrm{aC} \rightarrow \mathrm{M}$ \\
\hline Mag-04 & Sestroretsk & Russia & St.Petersburg & $60^{\circ} 08.02^{\prime} \mathrm{N}$ & $29^{\circ} 57.76^{\prime} \mathrm{E}$ & $15 \mathrm{~m}$ & $\mathrm{Q}, \mathrm{aC} \rightarrow \mathrm{M}$ \\
\hline Min-01 & North of Zoigê & China & Sichuan & $33^{\circ} 59.26^{\prime} \mathrm{N}$ & $102^{\circ} 44.77^{\prime} \mathrm{E}$ & $3450 \mathrm{~m}$ & worker \\
\hline Min-02 & $\begin{array}{l}\text { Northwest of } \\
\text { Songpan }\end{array}$ & China & Sichuan & $33^{\circ} 13.13^{\prime} \mathrm{N}$ & $103^{\circ} 44.50^{\prime} \mathrm{E}$ & $\mathrm{m}$ & n \\
\hline Min-03 & West of Yongdeng & China & Gansu & $36^{\circ} 41.26^{\prime} \mathrm{N}$ & $102^{\circ} 42.77^{\prime} \mathrm{E}$ & $2260 \mathrm{~m}$ & $\mathrm{Q}, \mathrm{aC} \rightarrow \mathrm{M}$ \\
\hline Occ- 01 & Mt. Ashland & USA & Oregon & $42^{\circ} 04.41^{\prime} \mathrm{N}$ & $122^{\circ} 43.41^{\prime} \mathrm{W}$ & $2050 \mathrm{~m}$ & $\mathrm{Q}, \mathrm{aC} \rightarrow \mathrm{M}$ \\
\hline Occ- 02 & Okotoks & Canada & Alberta & $50^{\circ} 43.25^{\prime} \mathrm{N}$ & $113^{\circ} 53.98^{\prime} \mathrm{W}$ & $1050 \mathrm{~m}$ & $\mathrm{Q}, \mathrm{aC} \rightarrow \mathrm{M}$ \\
\hline Occ-03 & Kitwanga & Canada & British Columbia & $55^{\circ} 06.12^{\prime} \mathrm{N}$ & $128^{\circ} 04.32^{\prime} \mathrm{W}$ & $175 \mathrm{~m}$ & M \\
\hline Occ-04 & Smithers & Canada & British Columbia & $54^{\circ} 48.48^{\prime} \mathrm{N}$ & $127^{\circ} 04.51^{\prime} \mathrm{W}$ & $685 \mathrm{~m}$ & M \\
\hline Pat-01 & Listvyanka & Russia & Irkutsk Oblast & $51^{\circ} 52.25^{\prime} \mathrm{N}$ & $104^{\circ} 50.15^{\prime} \mathrm{E}$ & $620 \mathrm{~m}$ & $\mathrm{Q}, \mathrm{aC} \rightarrow \mathrm{M}$ \\
\hline Pat- 02 & Chita & Russia & Zabaikalsky Krai & $52^{\circ} 00.54^{\prime} \mathrm{N}$ & $113^{\circ} 28.35^{\prime} \mathrm{E}$ & $750 \mathrm{~m}$ & $\mathrm{Q}, \mathrm{aC} \rightarrow \mathrm{M}$ \\
\hline Spo-01 & Kuopio & Finland & Northern Savonia & $62^{\circ} 54.56^{\prime} \mathrm{N}$ & $27^{\circ} 39.55^{\prime} \mathrm{E}$ & $211 \mathrm{~m}$ & Q \\
\hline Spo-02 & $\begin{array}{l}\text { Kuopio, Research } \\
\text { Garden }\end{array}$ & Finland & Northern Savonia & $62^{\circ} 54.55^{\prime} \mathrm{N}$ & $27^{\circ} 34.88^{\prime} \mathrm{E}$ & $95 \mathrm{~m}$ & Q \\
\hline Terre-01 & Assergi & Italy & Abruzzo & $42^{\circ} 25.57^{\prime} \mathrm{N}$ & $13^{\circ} 30.43^{\prime} \mathrm{E}$ & $972 \mathrm{~m}$ & Q \\
\hline Terre-02 & Alcala de los Gazules & Spain & Andalusia & $36^{\circ} 31.25^{\prime} \mathrm{N}$ & $05^{\circ} 38.86^{\prime} \mathrm{W}$ & $417 \mathrm{~m}$ & Q \\
\hline Terre-03 & Marburg & Germany & Hessen & $50^{\circ} 48.13^{\prime} \mathrm{N}$ & $08^{\circ} 48.59^{\prime} \mathrm{W}$ & $273 \mathrm{~m}$ & $\mathrm{Q}, \mathrm{aC} \rightarrow \mathrm{M}$ \\
\hline Terre-04 & St Andrews & UK & Scotland & $56^{\circ} 20.17^{\prime} \mathrm{N}$ & $02^{\circ} 48.45^{\prime} \mathrm{W}$ & $20 \mathrm{~m}$ & $\mathrm{Q}, \mathrm{aC} \rightarrow \mathrm{M}$ \\
\hline Sas-01 & Passo Tascusi & Italy & Sardinia & $40^{\circ} 01.82^{\prime} \mathrm{N}$ & $09^{\circ} 13.79^{\prime} \mathrm{E}$ & $870 \mathrm{~m}$ & $\mathrm{Q}, \mathrm{aC} \rightarrow \mathrm{M}$ \\
\hline Sas- 02 & Desulo & Italy & Sardinia & $40^{\circ} 00.53^{\prime} \mathrm{N}$ & $09^{\circ} 13.62^{\prime} \mathrm{E}$ & $898 \mathrm{~m}$ & $\mathrm{Q}, \mathrm{aC} \rightarrow \mathrm{M}$ \\
\hline Sas-03 & Passo di Caravai & Italy & Sardinia & $40^{\circ} 08.50^{\prime} \mathrm{N}$ & $09^{\circ} 20.10^{\prime} \mathrm{E}$ & $1120 \mathrm{~m}$ & Q \\
\hline Sas-04 & Cappannacia & Italy & Sardinia & $41^{\circ} 10.23^{\prime} \mathrm{N}$ & $09^{\circ} 19.17^{\prime} \mathrm{E}$ & $34 \mathrm{~m}$ & Q \\
\hline
\end{tabular}




\begin{tabular}{|l|l|l|l|l|l|l|l|}
\hline Code & \multicolumn{1}{|c|}{ Locality } & Country & \multicolumn{1}{|c|}{ Region } & Latitude & \multicolumn{1}{c|}{ Longitude } & Altitude & \\
\hline Can-01 & Tacaronte & Spain & Tenerife & $28^{\circ} 28.73^{\prime} \mathrm{N}$ & $16^{\circ} 24.91^{\prime} \mathrm{W}$ & $492 \mathrm{~m}$ & $\mathrm{Q}, \mathrm{aC} \rightarrow \mathrm{M}$ \\
Can-02 & Santiago el Teide & Spain & Tenerife & $28^{\circ} 18.23^{\prime} \mathrm{N}$ & $16^{\circ} 48.89^{\prime} \mathrm{W}$ & $948 \mathrm{~m}$ & $\mathrm{Q}$ \\
Can-03 & Mogan & Spain & Gran Canaria & $27^{\circ} 52.79^{\prime} \mathrm{N}$ & $15^{\circ} 43.77^{\prime} \mathrm{W}$ & $248 \mathrm{~m}$ & $\mathrm{Q}, \mathrm{aC} \rightarrow \mathrm{M}$ \\
Can-04 & Tafira Alta & Spain & Gran Canaria & $28^{\circ} 03.92^{\prime} \mathrm{N}$ & $15^{\circ} 27.61^{\prime} \mathrm{W}$ & $311 \mathrm{~m}$ & $\mathrm{Q}$ \\
\hline Terri-01 & Winchester & USA & New Hampshire & $42^{\circ} 46.19^{\prime} \mathrm{N}$ & $72^{\circ} 22.21^{\prime} \mathrm{W}$ & $140 \mathrm{~m}$ & $\mathrm{Q}, \mathrm{aC} \rightarrow \mathrm{M}$ \\
Terri-02 & Weld & USA & Maine & $44^{\circ} 41.02^{\prime} \mathrm{N}$ & $70^{\circ} 21.45^{\prime} \mathrm{W}$ & $375 \mathrm{~m}$ & worker \\
Terri-03 & Sturgeon Lake & Canada & Alberta & $55^{\circ} 14.58^{\prime} \mathrm{N}$ & $117^{\circ} 24.11^{\prime} \mathrm{W}$ & $715 \mathrm{~m}$ & $\mathrm{Q}$ \\
Terri-04 & Smithers & Canada & British Columbia & $54^{\circ} 48.48^{\prime} \mathrm{N}$ & $127^{\circ} 04.51^{\prime} \mathrm{W}$ & $685 \mathrm{~m}$ & $\mathrm{M}$ \\
\hline Tun-01 & Theog, Shimla Hills & India & Himachal Pradesh & $31^{\circ} 15.37^{\prime} \mathrm{N}$ & $77^{\circ} 27.34^{\prime} \mathrm{E}$ & $2740 \mathrm{~m}$ & $\mathrm{Q}, \mathrm{aC} \rightarrow \mathrm{M}$ \\
Tun-02 & Solang, Kullu valley & India & Himachal Pradesh & $32^{\circ} 18.50^{\prime} \mathrm{N}$ & $77^{\circ} 08.81^{\prime} \mathrm{E}$ & $2610 \mathrm{~m}$ & $\mathrm{Q}, \mathrm{aC} \rightarrow \mathrm{M}$ \\
Tun-03 & Vashisht, Kullu valley & India & Himachal Pradesh & $32^{\circ} 16.23^{\prime} \mathrm{N}$ & $77^{\circ} 11.38^{\prime} \mathrm{E}$ & $2730 \mathrm{~m}$ & $\mathrm{Q}$ \\
Tun-04 & Shogran, Naran & Pakistan & Northwest & $34^{\circ} 38.22^{\prime} \mathrm{N}$ & $73^{\circ} 26.85^{\prime} \mathrm{E}$ & $2360 \mathrm{~m}$ & $\mathrm{M}$ \\
& \multicolumn{1}{|l|}{ valley } & Frontier & & & \\
\hline
\end{tabular}

Tab. 2: List of Bombus samples (Cha = Cha, Gwanju, Hon = Hong, Gwanju, Pe = Pedersen, Copenhagen, TAN $=$ TANAKA, Kyoto, $\mathrm{Wu}=$ Wu, Beijing, $)$ used in the present analysis with Genbank numbers, and collection locality information.

\begin{tabular}{|c|c|c|c|c|c|}
\hline Species & Kam & GenBank \# & Locality & Region & Country \\
\hline \multirow[t]{2}{*}{ albocinctus } & Tan & AF279482 & ?? & Kamschatka Krai & Russia \\
\hline & Tan & AF279483 & Paramushir & Sakhalin Obl. & Russia \\
\hline franklini & Tan & AY694097 & Mt. Ashland & Oregon & USA \\
\hline \multirow[t]{4}{*}{ bypocrita } & Tan & AF385804 & ?? & Sakhalin & Russia \\
\hline & Tan & AF279492 & $? ?$ & Primorsk Distr. & Russia \\
\hline & Hon & EU401918 & $? ?$ & -- & South Korea \\
\hline & Tan & AF279489 & Kyoto & Honshu & Japan \\
\hline \multirow[t]{4}{*}{ ignitus } & Wu & GU085201 & $? ?$ & North China & China \\
\hline & Cha & \begin{tabular}{|l|} 
DQ870926 \\
\end{tabular} & ?? & -- & South Korea \\
\hline & Tan & AF279495 & ?? & Oita & Japan \\
\hline & Tan & AF279494 & Kyoto & Honshu & Japan \\
\hline lucorum & Tan & AF279497 & Yakutsk & Sakha Republic & Russia \\
\hline minshanicola & Wu & GU085202 & $? ?$ & North China & China \\
\hline \multirow[t]{2}{*}{ patagiatus } & Wu & GU085203 & $? ?$ & North China & China \\
\hline & Tan & AF279499 & Yakutsk & Sakha Republic & Russia \\
\hline \multirow[t]{2}{*}{ sporadicus } & Ped & AY181163 & Skute & Oppland & Norway \\
\hline & Tan & AF279500 & ?? & Primorsk Distr. & Russia \\
\hline
\end{tabular}

Tab. 3: Maximum Composite Likelihood Estimate of the Pattern of Nucleotide Substitution. The transition/transversion rate ratios are $\mathrm{k}_{1}=4.51$ (purines) and $\mathrm{k}_{2}=7.51$ (pyrimidines), the overall transition/transversion bias is $\mathrm{R}=1.566$.

\begin{tabular}{|l|rrrr|}
\hline & \multicolumn{1}{|c}{ A } & \multicolumn{1}{c}{ T } & \multicolumn{1}{c|}{ C } & G \\
\hline $\mathrm{A}$ & - & 5.15 & 1.48 & 6.68 \\
$\mathrm{~T}$ & 4.20 & - & 11.11 & 1.48 \\
$\mathrm{C}$ & 4.20 & 38.64 & - & 1.48 \\
$\mathrm{G}$ & 18.96 & 5.15 & 1.48 & - \\
\hline
\end{tabular}




\section{Results}

\section{Nucleotide frequencies and substitution parameters}

The aligned data matrix of 1257 bp length of 53 sequences included 984 invariant and 273 variable sites. Of these positions, 7 were parsimony uninformative (noise) and 266 parsimony informative (signal). However, differences in this pattern were evident in the codon positions. The first position comprised 51 informative positions; in the second position 7 were informative, in the third position 208 positions were informative. Table 3 gives the pattern of nucleotide substitutions estimated from the data with the maximum composite likelihood model (Mega). The nucleotide frequencies were $34.1(\mathrm{~A}), 41.8(\mathrm{~T}), 12.0(\mathrm{C})$ and $12.0(\mathrm{G})$, which proves the known strong $\mathrm{A}+\mathrm{T}$ bias typical for sequences of Hymenoptera.

\section{COI sequence divergence between and within subgenera in Bombus}

Investigations with the genetic marker COI produce a very detailed picture of genetic distances; some taxa show large genetic differences, some are smaller. Therefore it seems to be useful to 'calibrate' these differences: What is a typical genetic difference between species in the genus Bombus and what are the typical genetic differences between subgenera? Fig. 1 shows: estimates for genetic p-distances (1) between subgenera of the genus Bombus (median $=0.095$, interquartile range $=0.019)$, (2) between species of the subgenus Bombus s. str. (median $=0.059$, interquartile range 0.018 ) and (3) within species of the subgenus Bombus s. str. (median $=0.002$, interquartile range $=0.003$, with two outliers for B. cryptarum (with ssp. albocinctus and ssp. moderatus) and $B$. terrestris (with ssp. canariensis and ssp. sassaricus)). Details of the subgenera and taxa included in this statistic are summarized in Appendix I.

\section{'Bombus lucorum China'}

The genetic p-distances for the sequences $B$. lucorum/China included in the analysis as B. minshanicola are separated from $B$. lucorum by a p-distance of 0.035 , which far exceeds the p-distances of variable species such as $B$. terrestris and B. cryptarum. The mean p-distance to all Bombus s. str. species included in this investigation is 0.049 (range $0.035-0.086$ ) and fits completely into the p-distances found for species differences. Therefore the taxon $B$. minshanicola should be treated as a taxon separate from $B$. lucorum, most probably in the rank of a good species. For further information see Appendix II.

\section{COI sequence divergence between and within species Bombus sensu stricto}

Table 4 presents the matrix of genetic distances estimated by the TN model and as p-distances within and between the 14 taxa investigated. The infraspecific genetic variability was low for all taxa (TN distance 0.001-0.004). The infraspecific genetic variability was only larger (TN distance 0.013-0.014) in taxa with well-differentiated subspecies such as $B$. terrestris (with ssp. canariensis and ssp. sassaricus) and B. cryptarum (with ssp. albocinctus and ssp. moderatus). In contrast, the interspecific genetic variability was approximately one order of magnitude larger ( $\mathrm{p}$-distance 0.030-0,092, TN distance 0.030-0.103).

\section{Tree building by maximum likelihood models}

The maximum likelihood tree (Fig. 2) generated using the Bayesian MCMC (Markov Chain Monte Carlo) analysis with two 1257 bp full-length sequences for each taxon was based on the 
Tab. 4: Mean genetic distance within and between taxa. Diagonal and lower left: TAMURA-Nei model, rates among sites gamma distributed. Upper right: p-distance. [Sequences of $B$. franklini are shorter, distance data in italics].

\begin{tabular}{|l|llllllllllllll|}
\hline & Aff & Fra & Min & Luc & Hyp & Cry & Pat & Mag & Occ & Terri & Tun & Terre & Ign & SPO \\
\hline affinis & $\mathbf{0 . 0 0 2}$ & 0.049 & 0.041 & 0.049 & 0.061 & 0.059 & 0.062 & 0.054 & 0.062 & 0.057 & 0.065 & 0.069 & 0.071 & 0.081 \\
franklini & 0.046 & 0.001 & 0.037 & 0.044 & 0.069 & 0.054 & 0.057 & 0.047 & 0.051 & 0.048 & 0.063 & 0.069 & 0.083 & 0.093 \\
minshanicola & 0.049 & 0.041 & $\mathbf{0 . 0 0 3}$ & 0.033 & 0.044 & 0.031 & 0.036 & 0.036 & 0.051 & 0.038 & 0.047 & 0.053 & 0.063 & 0.076 \\
lucorum & 0.051 & 0.044 & 0.035 & $\mathbf{0 . 0 0 2}$ & 0.052 & 0.040 & 0.041 & 0.041 & 0.048 & 0.046 & 0.062 & 0.062 & 0.064 & 0.078 \\
hypocrita & 0.076 & 0.071 & 0.050 & 0.066 & $\mathbf{0 . 0 0 2}$ & 0.053 & 0.048 & 0.052 & 0.057 & 0.049 & 0.067 & 0.067 & 0.076 & 0.084 \\
cryptarum & 0.064 & 0.055 & 0.033 & 0.044 & 0.067 & $\mathbf{0 . 0 1 3}$ & 0.032 & 0.034 & 0.040 & 0.045 & 0.054 & 0.058 & 0.070 & 0.077 \\
patagiatus & 0.072 & 0.060 & 0.038 & 0.050 & 0.060 & 0.038 & $\mathbf{0 . 0 0 1}$ & 0.037 & 0.047 & 0.041 & 0.053 & 0.064 & 0.072 & 0.083 \\
magnus & 0.051 & 0.046 & 0.039 & 0.039 & 0.062 & 0.034 & 0.038 & 0.004 & 0.042 & 0.041 & 0.057 & 0.057 & 0.070 & 0.079 \\
occidentalis & 0.069 & 0.063 & 0.057 & 0.054 & 0.073 & 0.048 & 0.058 & 0.043 & $\mathbf{0 . 0 0 2}$ & 0.035 & 0.055 & 0.063 & 0.074 & 0.081 \\
terricola & 0.069 & 0.052 & 0.041 & 0.055 & 0.066 & 0.057 & 0.053 & 0.044 & 0.040 & $\mathbf{0 . 0 0 1}$ & 0.049 & 0.055 & 0.062 & 0.068 \\
tunicatus & 0.081 & 0.070 & 0.052 & 0.075 & 0.085 & 0.066 & 0.062 & 0.062 & 0.067 & 0.062 & $\mathbf{0 . 0 0 1}$ & 0.063 & 0.064 & 0.081 \\
terrestris & 0.083 & 0.072 & 0.059 & 0.066 & 0.085 & 0.067 & 0.072 & 0.061 & 0.078 & 0.067 & 0.079 & $\mathbf{0 . 0 1 6}$ & 0.067 & 0.072 \\
ignitus & 0.082 & 0.078 & 0.071 & 0.071 & 0.091 & 0.083 & 0.084 & 0.078 & 0.089 & 0.071 & 0.076 & 0.073 & $\mathbf{0 . 0 0 4}$ & 0.068 \\
sporadicus & 0.091 & 0.092 & 0.086 & 0.089 & 0.101 & 0.090 & 0.096 & 0.087 & 0.103 & 0.080 & 0.100 & 0.086 & 0.078 & $\mathbf{0 . 0 0 3}$ \\
\hline
\end{tabular}

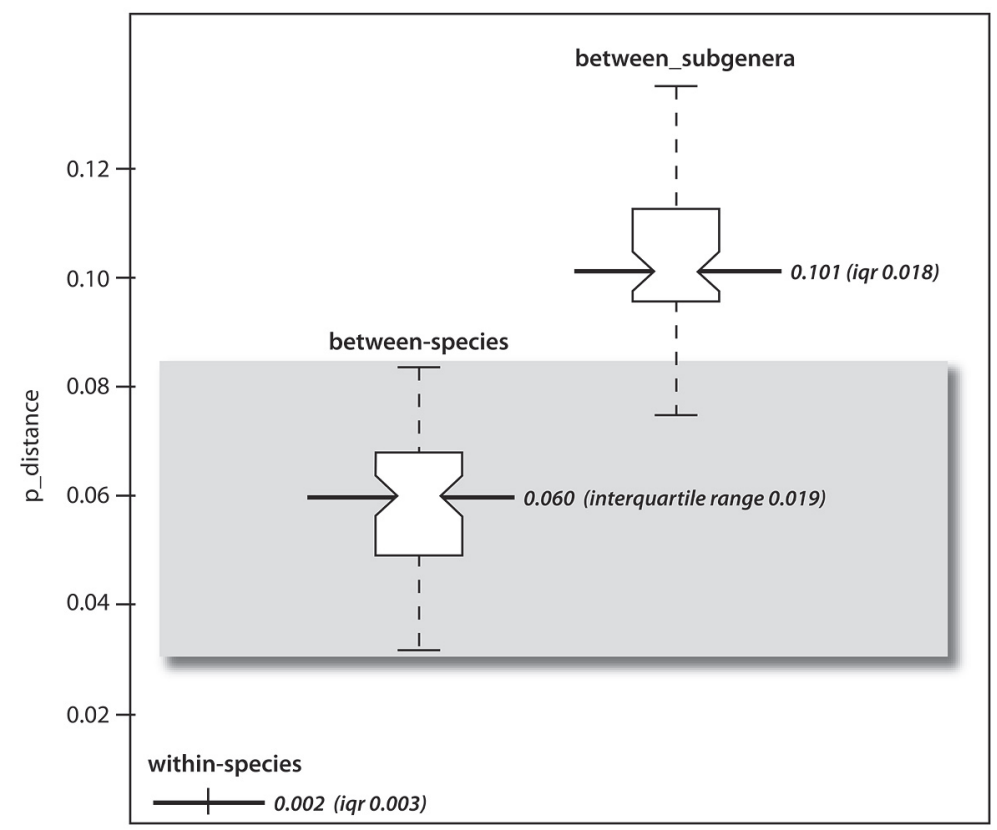

Fig. 1: Boxplots for between species and between subgenera median p-differences of COI sequences (849 bp length). The top and bottom of each box are the $25^{\text {th }}$ and $75^{\text {th }}$ percentiles of the samples, the distance is the interquartile range (iqr $=$ middle $50 \%$ of samples), the whiskers (broken lines) the range of the samples. Notches display the variability of the median between samples; the width of a notch is computed so that boxplots whose notches do not overlap have different medians at the $5 \%$ significance level.

general time-reversible model of base substitution (GTR plus gamma), and was simulated for 5000000 generations to achieve stationary with sampling every 10 generations and a "burn-in" of 5000 generations. For comparison and to increase the geographical range, GenBank sequences 


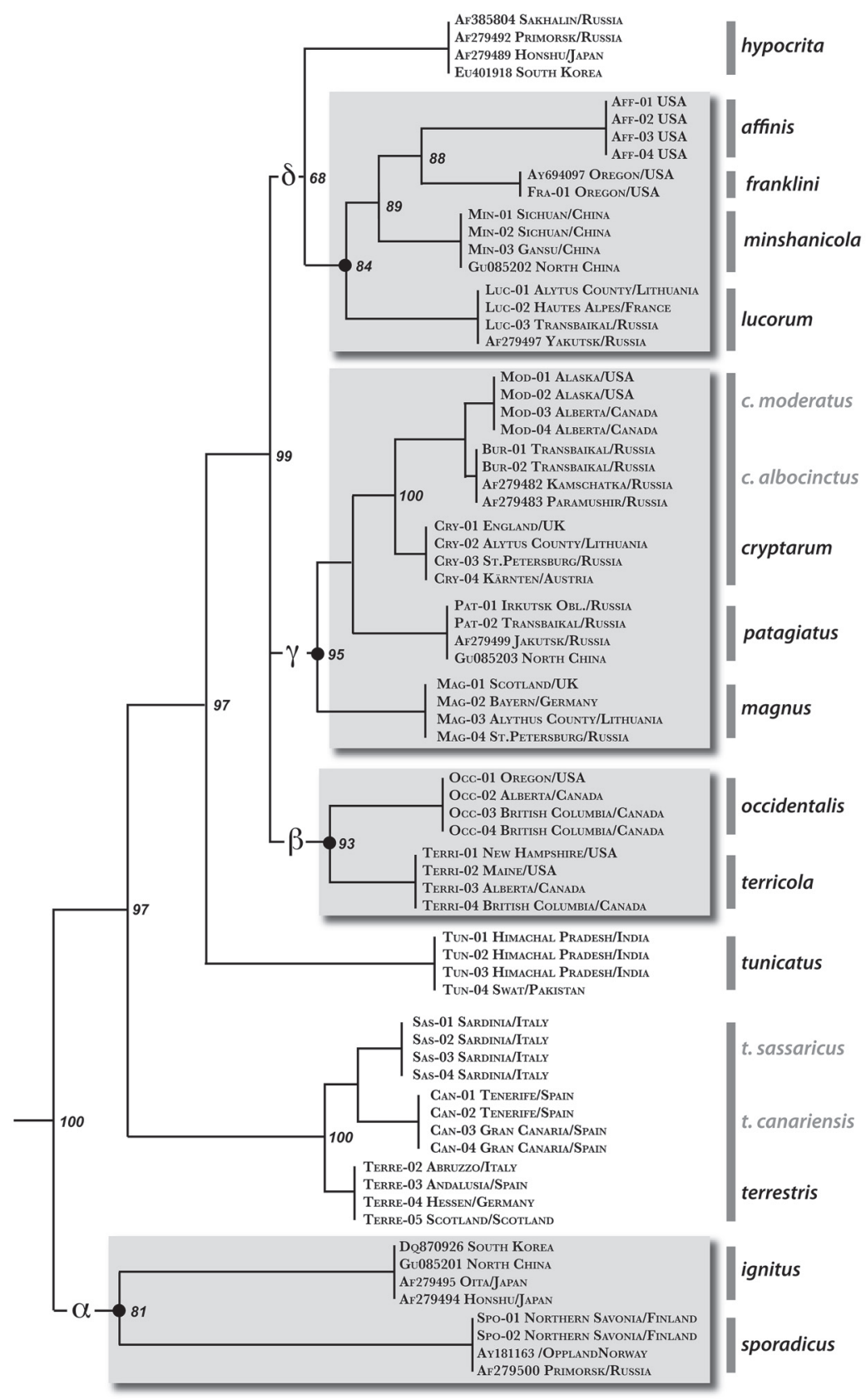

Fig. 2: Tree topology calculated as Maximum-Likelihood tree using Bayesian MCMC analysis with the general time reversal model of base substitutions with gamma distribution. 


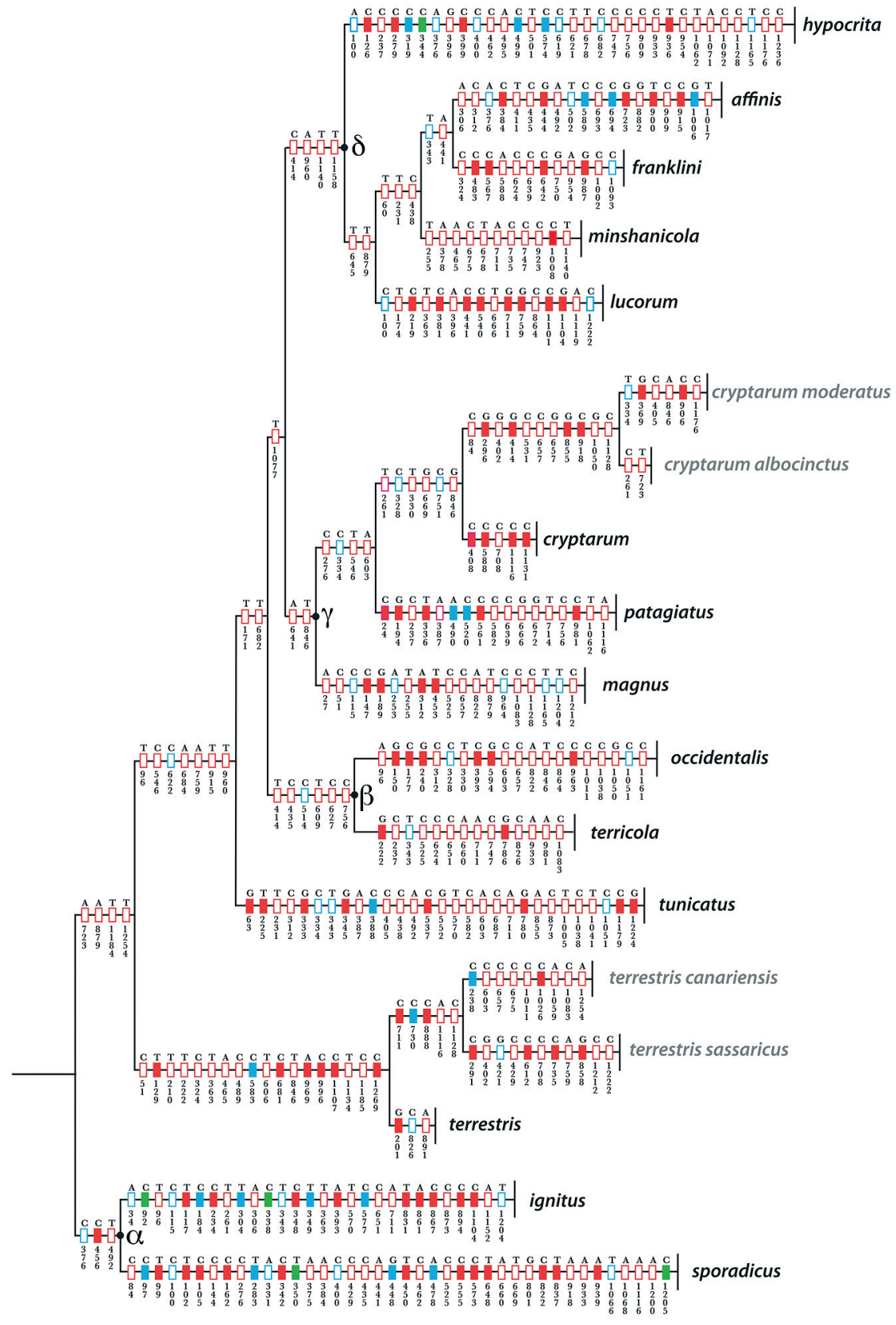

Fig. 3: Observed diagnostic character changes with position numbers mapped onto the Maximum-Likelihood tree. Box filled = unambiguous diagnostic character change, box open = unambiguous character change, first position $=$ blue, second position $=$ green and third position $=$ red . 
were included. Two of the 14 taxa were well separated (B. terrestris \& B. tunicatus), and the rest formed distinct clusters: cluster $\alpha$ with B. sporadicus and B. ignitus and a posterior probability of 0.81 , cluster $\beta$ with $B$. occidentalis and $B$. terricola and a posterior probability of 0.93 , cluster $\gamma$ with $B$. magnus, $B$. patagiatus, and $B$. cryptarum and a posterior probability of 0.95 , and cluster $\delta$ with $B$. hypocrita, B. lucorum, B. minshanicola, B. franklini and B. affinis and a posterior probability of 0.68 . Because the support for cluster $\delta$ has only a 0.68 probability, B. hypocrita is also probably completely separate.

\section{Tree building by diagnostic characters}

As there are no gaps in the alignments of the COI sequences, single nucleotide sites can be used as positional homologies (Hillis 1994). In MacClade, the changes at the nodes and the diagnostic characters at the last branch of the terminal units can be investigated in detail (MADDIsON \& MADDISON 2002), and a tree with the classical tools for morphological characters can be built (Fig. 3). With the large number of diagnostic characters available it is normal that not all of these changes are unambiguous, but each of the taxa investigated is characterized by between 11-40 unambiguous characters and with the exception of $B$. minshanicola 5-12 'unique' diagnostic positions. Clusters $\alpha$ to $\delta$ of the MrBayes maximum likelihood tree are also distinctly separate in this cladistic tree, and the larger infraspecific variability of B. terrestris and B. cryptarum is 'explained' by the differentiation of these species into genetically isolated subspecies.

\section{Discussion}

\section{'B. lucorum China', the neglected taxon B. minshanicola Bischoff, 1936}

CAmeron et al. (2007) reported a sequence referred to as 'B. lucorum/China' that differs from the sequences of $B$. lucorum from Europe, a result confirmed by an unpublished COI sequence of $B$. lucorum from North China, which also proves that this B. lucorum/China is very different from the typical European $B$. lucorum, defined by its morphology, male labial gland secretions and mitochondrial DNA markers (COI). This ' $B$. lucorum/China' is thus not identical to the taxon B. lucorum.

As the subgenus Bombus s. str. has been thoroughly studied and has already delivered a huge number of colour variants and names (KRÜGER 1951, 1954, 1956, 1958), it seems improbable that this B. lucorum/China does not already have a name. B. lucorum lanchouensis Vogt 1908 was synonymized by TKalcU (1967) with B. patagiatus as B. patagiatus ssp. lanchouensis. Therefore only one taxon remains from the area (Northern Sichuan \& Gansu/China) from which this unknown B. lucorum China has been described: B. minshanicola Bischoff, 1936, described as B. terrestris ssp. minshanicola and transferred to B. lucorum by KRÜGER (1951, p. 196).

The morphological characters in the Bombus lucorum complex are not well understood, mainly because the variability in the characters has not been thoroughly investigated. Without good morphological characters identification is unreliable. The species-specific male labial gland secretions and the species-specific 'unique' positions of the COI sequences are the only tools available so far for the safe identification of specimens. However, the case of $B$. minshanicola may be less problematic, because the description of Bischoff (1936) and the type material showed clear differences in colouration compared to the European B. lucorum, which might be used to characterize specimens of $B$. minshanicola and most probably prove its identity with ' $B$. lucorum/China'. For further information see Appendix II. 


\section{Genetic variability in B. cryptarum and B. terrestris}

Bombus terrestris is one of the species in the subgenus Bombus s. str. that is known for its geographical variation, and besides colour forms also includes taxa in the rank of subspecies (KRÜGER 1951, 1954; RASmont et al. 2008). Some isolated island populations, such as B. terrestris ssp. sassaricus (Tournier 1890) from Italy/Sardinia and B. terrestris ssp. canariensis (PÉrez 1895) from Spain/ Canary Islands are distinctly different in colouration. The separation of these island populations from specimens of the European continent was confirmed by a genetic p-distance of 0.014 and a difference of 11 unambiguous positions (including 4 'unique' positions) for $B$. terrestris sassaricus, and a genetic p-distance of 0.022 and a difference of 9 unambiguous positions (including 2 'unique' positions) for $B$. terrestris canariensis. Whereas more or less invariable species have a genetic p-distance of 0.001 to 0.003 , in the variable $B$. terrestris the mean genetic p-distance is 0.016 .

It has been shown that the North American taxon B. moderatus (Cresson 1863) and the East Asian taxon B. albocinctus (SMITH 1854) are most probably subspecies of the species B. cryptarum (BERTsCH et al. 2010a), which results in a mean genetic p-distance of 0.013 within B. cryptarum, about the same order of magnitude as within B. terrestris. As long as B. terrestris sassaricus and $B$. terrestris canariensis are treated as subspecies, the same should apply for B. cryptarum albocinctus and B. cryptarum moderatus.

\section{Which Bombus sensu stricto taxa are good species?}

This question has been in dispute for a very long time. So far in most cases the assignment is based on colouration and geographical provenance but in some cases the assignment of specimens is in dispute. As long as objective criteria are lacking the question of lumping or splitting taxa remains a more or less subjective decision, based on different 'species concepts'. The latest checklists (Williams 1998; Williams et al. 2008) recognize 10 species; Williams (2010) treats B. terricola and $B$. occidentalis as separate species and therefore recognizes 11 species. With the mitochondrial DNA markers we have for the first time an objective measure of the genetic distance between the taxa of the subgenus Bombus s. str., with the result that 14 taxa might be 'good' species: the North American B. terricola and B. occidentalis are split into two species and B. cryptarum, B. magnus and $B$. minshanicola are added to the 10 species of Williams et al. (2008). Specimens of the subgenus Bombus s. str. are well represented in museum collections and in most parts of the world the taxa of the subgenus Bombus s. str. have been thoroughly investigated. It is possible that a few more taxa with the rank of species may be detected in parts of the Himalayas and China, but this should be done by genetic markers and labial gland secretions, not just by differences in colouration or doubtful morphological characters. The question as to how far these 14 'species' can also be established as morphological species is still open, and obviously the morphological differences are small (at least in some of these taxa). Thus it is only after safe assignment that an investigation of the morphological characters and their variability can be carried out.

Uniting B. occidentalis and B. terricola into a broader unit $B$. terricola, or separating $B$. albocinctus from $B$. cryptarum and $B$. canariensis from $B$. terrestris, is more a matter of taste rather than scientific insight. For further field studies and experimental work it is essential to give a proper name to the specimens investigated, but the specific rank of the taxon is not really important. The name is just a means to make sure that everybody understands which taxon has been under investigation. In times when the investigation of biodiversity is one of the central themes in biology and the definition of the rank 'species' is in dispute, the 'lumping' of taxa is not really helpful. It is an unnecessary loss of information. 


\section{Phylogenetic relationships based on a single gene?}

The trees presented in this investigation were built with programs simulating phylogenetic relationships, but they should be read as a graphic display of genetic distances rather than a real phylogeny. More sequences and more genes will have to be investigated before a reliable phylogeny can be constructed. The phylogeny of CAMERON et al. (2007) is based on the 16S mitochondrial gene and four nuclear genes, but all the information on these genes was 'lumped' into one MrBayes simulation. A closer look at the GenBank data reveals that in some of these genes the genetic difference between the taxa of the subgenus Bombus s. str. is so small that the trees are poorly resolved. If the phylogenies for the different genes are calculated separately, we obtain trees with contradictory phylogenies (see CAMERON et al. 2007, supplementary materials). This result is not unexpected; evolution is a complicated procedure and different characters evolve at different speeds and sometimes in different directions. A simulation of phylogenetic evolution based on maximum likelihood models is always a simulation; a process that took place a long time ago can never be reconstructed with certainty, and will always remain a hypothesis.

\section{Acknowledgments}

Prof. R. Thorp (Davis/California) gave valuable advice and helped to collect the male B. franklini (AY694097), Prof. J.R.J. van Asperen de Boer (Amsterdam/Netherlands) supplied the specimens of B. franklini (FRA-01) and B. minshanicola (MIN-01, MIN-02) from his collection. Prof. B. Heinrich (Burlington/Vermont) collected the specimen of B. terricola (TERRI-02) from Maine/USA. Dr. M. Ito (Sapporo) confirmed the identity of the Far East GenBank sequences B. cryptarum (AF279482/83) with B. albocinctus. Dr. An Jian-dong (Beijing/China) collected males of 'B. lucorum/China' for labial gland investigations. Prof. M. Hrabé de Angelis (Institute of Experimental Genetics, Helmholtz Zentrum München, Germany) kindly allowed me to work in his institute and laboratories, and Dr. G. K.-H. Przemeck (Institute of Experimental Genetics, Helmholtz Zentrum München, Germany) designed the primers, and gave, with much patience, initial instructions on how to extract DNA and perform a PCR, and always helped to obtain reliable ABI sequences. I would like to thank them all for their valuable help.

\section{References}

Bertsch, A. 2009: Barcoding cryptic bumblebee taxa: B. lucorum, B. crytarum and B. magnus, a case study (Hymenoptera: Apidae: Bombus). - Beiträge zur Entomologie 59: 287-310.

Bertsch, A.; Hrabé de Angelis, M. \& Przemeck, G.K.-H. 2010a: Phylogenetic relationships of the bumblebees Bombus moderatus, B. albocinctus, B. burjaeticus, B. florilegus and B. cryptarum based on mitochondrial DNA markers: a complex of closely related taxa with circumpolar distribution. (Hymenoptera: Apidae: Bombus). - Beiträge zur Entomologie 60: 13-32.

Bertsch, A.; Hrabé de Angelis, M. \& Przemeck, G.K.-H. 2010b: A phylogenetic framework for the North American bumblebee species of the subgenus Bombus sensu stricto (Bombus affinis, B. franklini, B. moderatus, B. occidentalis \& B. terricola) based on mitochondrial DNA markers (Hymenoptera: Apidae: Bombus). - Beiträge zur Entomologie 60: 229-242.

Bischoff, H. 1936: Schwedisch-chinesische wissenschaftliche Expedition nach den nordwestlichen Provinzen Chinas. 56. Hymenoptera. 10. Bombinae. - Arkiv för Zoologi 27A (no 38): 1-27.

Cameron, S. A.; Hines, H. M. \& Williams, P. 2007: A comprehensive phylogeny of the bumble bees (Bombus). - Biological Journal of the Linnean Society 91: 161-188.

Cha, S. Y.; Yoon, H. J.; Lee, H. E. M.; Yoon, M. H.; Hwang, J. S.; Bin, B. R.; Han, Y. S. \& Kim, I. 2007: The complete nucleotide sequence and gene organization of the mitochondrial genome of the bumblebee, Bombus ignitus (Hymenoptera, Apidae). - Gene 392: 206-220. 
Hillis, D. M. 1994. Homology in molecular biology. In Homology, The Hierarchical Basis of Comparative Biology. - Edited by B. H. Hall. - Academic Press, London New York: pp. 197-227.

Huelsenbeck, J. P. \& Ronquist, F. 2001: MrBayes: Bayesian inference of phylogeny. - Bioinformatics 17: 754-755.

Kawakita, A.; Sota, T.; Ito, M.; Ascher, J. S.; Tanaka, H.; Kato, M. \& Roubik, D.W. 2004: Phylogeny, historical biogeography and character evolution in bumble bees (Bombus: Apidae) based on simultaneous analysis of three nuclear gene sequences. - Molecular Phylogenetics and Evolution 31: 799-804.

KRÜGER, E. 1951: Phänoanalytische Studien an einigen Arten der Untergattung Terrestribombus O. Vogt (Hymenoptera, Bombidae). I. Teil. - Tijdschrift voor Entomologie 93: 141-197.

KRÜGER, E. 1954: Phänoanalytische Studien an einigen Arten der Untergattung Terrestribombus O. Vogt (Hymenoptera, Bombidae). II. Teil. - Tijdschrift voor Entomologie 97: 263-298.

KRÜGER, E. 1956: Phänoanalytische Studien an einigen Arten der Untergattung Terrestribombus O. Vogt (Hymenoptera, Bombidae). II. Teil. - Tijdschrift voor Entomologie 99: 75-105.

KRÜGER, E. 1958: Phänoanalytische Studien an einigen Arten der Untergattung Terrestribombus O. Vogt (Hymenoptera, Bombidae). III. Teil. - Tijdschrift voor Entomologie 101: 283-344.

Kumar, S.; Nei, M.; Dudley, J. \& Tamura, K. 2008: MEGA. A biologist-centric software for evolutionary analysis of DNA and protein sequences. - Briefings in Bioinformatics 9: 299-306.

Maddison, W. P. \& Maddison, D. R. 2002: MacClade Analysis of Phylogeny and Character Evolution. - Sunderland, Sinauer Associates: 398 pp.

Pedersen, B. V. 1996: A phylogenetic analysis of cuckoo bumblebees (Psithyrus, Lepelletier) and bumblebees (Bombus; LATREILLE) inferred from sequences of the mitochondrial gene cytochrome oxidase I. - Molecular Phylogenetics and Evolution 5: 289-297.

Pedersen, B. V. 2002: European bumblebees (Hymenoptera: Bombini) - phylogenetic relationships inferred from DNA sequences. - Insect Systematics \& Evolution 33: 361-386.

Peng, W-J.; Huang, J-X.; Wu, J.; AN, J-D. 2009: Geographic distribution and bionomics of six bumblebee species in North China [in Chinese]. - Chinese Bulletin of Entomology 46 (1): 115-120.

Posada, D. 2008: jModelTest: phylogenetic model averaging. - Molecular Biology and Evolution 25: 1253-1256.

Rasmont, P.; Coppée, A.; Michez, D. \& De Meulemeester, Th. 2008: An overview of the Bombus terrestris (L. 1758) subspecies (Hymenoptera: Apidae). - Annales Societé Entomologique France (n. s.) 44: 243-250.

Sjöstedt, Y. \& Hummel, D. 1932: Schwedisch-chinesische wissenschaftliche Expedition nach den nordwestlichen Provinzen Chinas. Einleitung. - Arkiv för Zoologi, 25A (no 3): 1-16, 2 maps.

TAMura, K. \& Nei, M. 1993: Estimation of the number of nucleotide substitutions in the control region of mitochondrial DNA in humans and chimpanzees. - Molecular Biology and Evolution 10: 512-526.

Tamura, K.; Dudley, L.; Nei, M. \& Kumar, S. 2007: Mega 4.0: Molecular Evolutionary Genetics Analysis (Mega) software version 4.0. - Molecular Biology and Evolution 24: 1596-1599.

Tkalců, B. 1961: Zur Hummelfauna der Umgebung Kuku-Nors (Hymenoptera, Bombinae). - Acta societatis entomologicae chechosloveniae 58: 344-379.

Tkalců, B. 1967. Sur deux espèces de Bourdons décrites par William Nylander. - Bulletin de la Société Entomologique de Mulhouse 1967: 41-58.

Vogt, O. 1909: Studien über das Artproblem. 1. Mitteilung. Über das Variieren der Hummeln 1. Teil. - Sitzungsberichte der Gesellschaft Naturforschender Freunde zu Berlin Jahrgang 1909: 28-84.

Williams, P. 1998: An annotated checklist of bumble bees with an analysis of patterns of description (Hymenoptera: Apidae, Bombini). - Bulletin of the British Museum (Natural History). - Entomology 67: 79-152.

WiLLIAMs, P. 2010: www.nhm.ac.uk/researchcuration/research/projects/bombus/index.html 
Williams, P. H.; Cameron, S. A.; Hines, H. M.; Cederberg, B. \& Rasmont, P. 2008: A simplified subgeneric classification of the bumblebees (genus Bombus). - Apidologie 39: 46-74.

Williams, P.; Tang, Y.; YaO, J. \& Cameron, S. 2009: The bumblebees of Sichuan (Hymenoptera: Apidae, Bombini). - Systematics and Biodiversity 7: 101-190.

WinkleR, D. 1997: Waldvegetation in der Ostabdachung des Tibetischen Hochlands und die historische und gegenwärtige Entwaldung. - Erdkunde 51: 143-163.

Author's address:

Prof. Dr. Andreas BerTsch

Department of Biology, Philipps-University Marburg

Karl-von-Frisch Straße 8

35032 Marburg

Germany

e-mail: bertsch@staff.uni-marburg.de
Subject editor:

Prof. Dr. H. H. DATHE

\section{Appendix I}

Sequences without GenBank numbers are unpublished sequences from BERTSCH et al. Statistics calculated and plotted with the Statistics Toolbox ${ }^{\mathrm{TM}}$ of Matrab. Sequence length $848 \mathrm{bp}$, COI positions 262-1110.

(01) Alpinobombus:

alpinus, balteatus AY181097, hyperboreus AY181107, polaris AY181144.

(02) Bombus s. str.:

albocinctus, cryptarum, hypocrita AF279489, ignitus AF279496, magnus, lucorum, patagiatus, terrestris, tunicatus.

(03) Confusobombus: confusus AY181098.

(04) Kallobombus: soroeensis AY181159.

(05) Megabombus:

argillaceus, consobrinus, gerstaeckeri, hortorum, ruderatus.

(06) Melanobombus:

lapidarius AY181114, sicheli AY181157, incertus.

(07) Pyrobombus:

cingulatus AF279534, haematurus, hypnorum AY181110, jonellus AY181113, lapponicus, monticola AY181130, pratorum AY181147, pyrenaeus AY181151.

(08) Sibiricobombus: niveatus.

(09) Subterraneobombus:

distinguendus, fragrans, melanurus AF385818, subterraneus.

(10) Thoracobombus:

deuteronymus AF279553, humilis AY181106, mucidus, muscorum AY181135, pascuorum AY181139, ruderarius AY181154, schreberi, sylvarum AY181166, veteranus, zonatus. 


\section{Appendix II}

Description by H. Bıschoff, 1936, Arkiv för Zoologie vol. 27A, pp. 2-3.

B. terrestris minshanicola $\mathrm{n}$. subsp.

Eine verhältnismäßig kleine Form, die ausgezeichnet ist durch schmale, gelbe Binden und geringe Ausdehnung der weißen Behaarung an der Hinterleibsspitze. Die weiße Behaarung beginnt erst am Hinterrand des 4. Abdomen Tergits. Die schwarze Zone des Abdomens erscheint dadurch fast doppelt so breit wie die gelbe Querbinde. Vorn am Clypeus und Labrum ist die Behaarung zu einem erheblichen Teil gebräunt. Die Behaarung der Unterseite ist vorherrschend schwarz.

Beim Männchen beginnt die weiße Endbehaarung am Hinterrand des fünften Tergits.

H. BIschoff describes the typical colouration of the abdomen of this taxon, which makes the specimen of the type series and the specimens that I have seen (from the North of Sichuan $\&$ Gansu) characteristically different from typical B. lucorum. By the colouration alone it could easily be taken for a small $B$. terrestris, especially as the yellow of the museum material is not 'lemon yellow' but more or less brownish.

The males do not show the usual 'blonde' colouration of B. lucorum, and the scutellum and the first tergite are black not yellow as in typical $B$. lucorum. I cannot confirm that the white colouration at the end of the abdomen starts at the posterior border of the fifth tergite (see description by Bischoff). In the fresh males I have seen from Gansu the white hairs start at the posterior border of the fourth tergite, but the white hairs are so sparse that the black exoskeleton remains visible and the end of the abdomen looks more black than white.

Type series: The specimens of the type series Riksmuseet Stockholm (Minshan Southern Gansu/ China) could not be found (E-mail from Hymenoptera curator, Dr. Hege Vårdal).

Exact localities after Sjöstedt \& Hummel 1932:

1 우 29.07.1930, camp 50, [Drakana], $3100 \mathrm{~m}$; 13 worker, 25.07.1930, camp 48, [Shi-men], $3500 \mathrm{~m} ; 28 . / 29.07 . \&$ 12.08.1930, camp 50, [Drakana], $3100 \mathrm{~m} ; 02.08 .1930$, camp 53, [Jango], 3100-3600 m; 19.10.1930, camp 74, [Liang-chia-pa], $1300 \mathrm{~m} ; 1$ o, 03.09 .1930 , camp 64, [Tjeggala], Passhöhe Min-Shan 3700 m, alpine meadow.

Specimens seen:

(1) paratype specimens Museum für Naturkunde Berlin:

2 worker, 27.07.1930, camp 49 Kuan-ki-shan, valley south of the pass, ravine, shrubbery, $3600 \mathrm{~m}$, 1 , 29.07.1930, camp 50 Drakana, valley south of the Minshan main ridge, $3100 \mathrm{~m}$.

(2) Collection Dr. van Asperen de Boer, Amsterdam: All specimens China/ Northern Sichuan: 1 worker, 15.08.2009, Rd Jiuzhaigo 53 km N Songpan, 3320 m, Epilobium; 2 worker, 11.08.2009, N. Zoige Rd Baxi 55 km NE, 3450 m, Cirsium; 1 worker, 14.08.2009, Rd Huanglong 51 km NE Singpan, 3560 m, Cirsium; 1 ơ, 03.08.2009, 5 km N Miyalo, 2830 m, Vicia. 
(3) Fresh material:

10 o $^{\star} \mathrm{o}^{\star}, 23.08 .2010$, Yongdeng, Gansu Prov. Forest Border, 36 41.26' N, 102 42.77' E, $2260 \mathrm{~m}$, Cirsium leo.

The localities Southern Gansu (Dr. H. Hummel) and Northern Sichuan (Dr. van Asperen de Boer) are very close (60 - $100 \mathrm{~km}$ distance). As the specimens inspected resemble the description given by Dr. H. Bischoff, and as the taxon is quite abundant in this area (Williams et al., 2009, Fig. 271 and 275 for Sichuan, and 'distributed widely in Gansu' according to information from Dr. AN) B. lucorum/China and B. minshanicola Bischoff probably belong to the same taxon. An attempt to verify this assumption by sequencing one of the paratype specimens from the Museum für Naturkunde, Berlin was not successful; no reasonable DNA could be extracted.

\section{Morphology \& morphometry}

Remains to be studied using more material.

\section{Colouration}

Should be investigated in fresh material; according to Williams et al. (2009) the yellow colouration is 'lemon yellow', but that is not the case in the museum material seen. TKaLCU (1961) reported characteristic colour changes in museum specimens, which become brownish. The fresh males I have seen from Gansu/China show a bright yellow colouration with some black hair interspersed into the collare. The long hairs of the head (vertex, between the antennae \& at clypeus) are black, with shorter feathered white-greyish hair intermixed. Similar to B. lucorum the tips of the black hairs are somehow whitened (pulverulence), not as much as in 'blonde' males of B. lucorum but still quite obvious and characteristic. The best characters of the colouration as described by Bischoff (1936) are the narrow bands (collare \& 2. tergite) and the broad black section between the yellow band of the second tergite and the white end of the abdomen.

\section{Distribution \& ecology}

Distributed in the higher mountains of Sichuan (Williams et al. 2009; Fig. $271 \& 275$ ) and Gansu provinces ('widely distributed' according to an e-mail from AN), rare in Shanxi province and North China (Peng et al. 2009, Fig. 3). Restricted to the higher altitudes (upper montane zone), lower border of subalpine forest zone in Sichuan at about $3500 \mathrm{~m}$ (WINKLER 1997, Abb. 3).

\section{DNA sequences}

B. lucorum, B. hypocrita, B. minshanicola, B. franklini \& B. affinis form a separate cluster (Fig. 4), B. minshanicola is connected to the North American B. franklini \& B. affinis with $96 \%$ posterior probability.

\section{Male labial gland secretions}

The male labial gland secretions of $B$. lucorum are characterised by the main component Ethyl 9-tetradecenoate (58\%), which is found only in traces in B. minshanicola, whereas the main component in B. minshanicola is Ethyl dodecanoate (35\%). In B. minshanicola 2,3-Dihydro-farnesol is found in large quantities (26.6\%), a substance that is completely absent in B. lucorum (Table 5 , BERTSCH \& SCHWEer, unpublished). 


\section{Conclusion}

B. mishanicola is essentially different from typical B. lucorum in (1) distribution, (2) colouration, (3) DNA marker (COI) and (4) male labial gland secretions. The genetic distance to the next neighbour taxa and the difference in compounds of the male labial glands prove $B$. minshanicola to be a separate species.

Tab. 5: Characteristic compounds of the male labial glands of B. lucorum and B. minshanicola. Compounds with more than $10 \%$ in bold.

\begin{tabular}{|l|ccc|}
\hline & MG & lucorum & minshanicola \\
\hline Ethyl dodecanoate & 228 & 9,56 & $\mathbf{3 4 , 6 1}$ \\
\hline Tetradecanal & 212 & -- & 1,86 \\
\hline 2,3-Dihydrofarnesal & 222 & -- & 1,76 \\
\hline 2,3-Dihydrofarnesol & 224 & -- & $\mathbf{2 6 , 6 0}$ \\
\hline Ethyl 9-tetradecenoate & 254 & $\mathbf{5 8 , 4 0}$ & 0.02 \\
\hline Hexadecan-1-ol & 242 & 3,54 & 3,60 \\
\hline 9,12-Octadecadien-1-ol & 266 & 1,64 & 0,54 \\
\hline 9,12,15-Octadecatrien-1-ol & 264 & 4,66 & 3,68 \\
\hline Ethyl 9-octadecenoate & 310 & 0,82 & $\mathbf{1 6 , 3 6}$ \\
\hline 15-Eicosen-1-ol & 296 & 0,10 & 1,54 \\
\hline
\end{tabular}

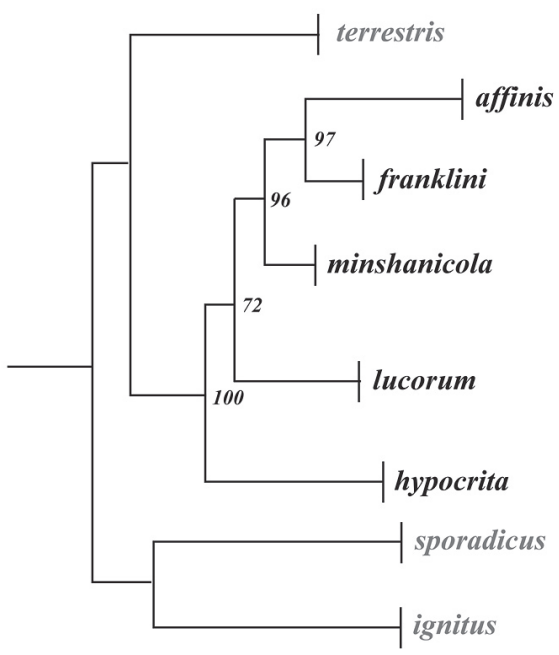

Fig. 4: MrBayes maximum likelihood tree calculated for cluster $\delta: B$. affinis, B. franklini, B. minshanicola, B. lucorum and B. hypocrita with outgroup B. soroeensis. 